\title{
5
}

\section{EL MITO DE LA ARGENTINA LAICA. CATOLICISMO, POLÍTICA Y ESTADO}

Fortunato Mallimaci

Capital Intelectual, Buenos Aires, 2015. 269 páginas. ISBN 978-987-6144-79-7

Pablo Salomon

Este libro aborda los vínculos y articulaciones existentes entre lo católico y lo político en la sociedad y el Estado argentinos. Se analizan lo que el autor llama momentos típicos-ideales en los que se visualizan con mayor nitidez esas vinculaciones. El eje central del libro se focaliza en los años 1930-1960, debido a que Mallimaci considera ese período como el momento de afianzamiento de la matriz religiosa hegemónica que persiste hasta la actualidad. No obstante, construye una periodización que reconoce tres etapas; en primer lugar desde inicios del siglo XIX hasta 1930, cuando se desarrolla un catolicismo sin Iglesia; desde 1930 hasta 1976, período en el que se da un catolicismo con Iglesia; y finalmente, desde 1976 hasta la actualidad, lapso caracterizado por la existencia de una Iglesia sin catolicismo.

Malimacci advierte sobre la complejidad de considerar lo católico y lo político. Ambos conceptos van más allá de los marcos institucionales y no son monolíticos. Por ello, prefiere hablar de catolicismos en plural, debido a que no solamente incluye a la Iglesia sino también a los especialistas religiosos, a los movimientos católicos e incluso a los fieles católicos considerados individualmente. Del mismo modo, lo político se presenta como un espectro que va desde los partidos políticos, los movimientos sociales, fundaciones y ONG hasta las protestas callejeras y virtuales, las intervenciones de acción directa, los recitales de música y los partidos de fútbol. Una hipótesis central atraviesa 
todo el libro y considera que es necesario deconstruir un mito en Argentina: el creer que en sus orígenes históricos hubo una sólida y única República laica, democrática y liberal, y que en las décadas de 1920 y 1930 fue suplantada por otra sólida y única Nación católica, orgánica y nacionalista. Debemos tomar distancia del mito de la Argentina laica.

El libro está organizado en una introducción, seis capítulos y una reflexión final. En el capítulo primero, titulado "Religiones, estados y naciones: la disputa por lo sagrado y el sentido. Nacimiento del catolicismo institucional argentino", el autor realiza una mirada de largo plazo desde los inicios del siglo XIX hasta 1930, destacando los rasgos significativos en la relación entre el poder político y el catolicismo. Antes de las revoluciones de independencia el catolicismo era regulado por los reyes españoles para luego construir una reformulación signada por un vínculo más estrecho con el Vaticano. Además, las revoluciones no fueron anticlericales ni se proponían cambiar la religión de sus sociedades, que era predominantemente católica. Los primeros gobiernos poscoloniales reconocían al catolicismo y la Constitución Nacional de 1853 condiciona que el presidente profese dicha religión. Si bien hubo un pensamiento liberal representado en la generación del '37, Alberdi, Sarmiento y Frías tuvieron que negociar sus postulados con la tradición católica cuando emprendieron distintos proyectos. El autor considera que la construcción del orden político se pensó con articulaciones con lo religioso. Hacia fines del siglo XIX e inicios del siglo XX, la élite política consideró que la religión ocupaba un lugar civilizatorio en la sociedad y la imaginaba como un aparato ideológico a su servicio. El Estado había creado una liturgia cívica, símbolos patrios y un concepto de patria con fuertes características sagradas.

Los capítulos 2 y 3, titulados "Catolicismo intransigente e integral" y "Una cultura católica antiliberal y anticomunista en marcha", respectivamente, abordan el período que se extiende desde 1930 hasta 1946. En la Argentina, el catolicismo intransigente e integrista encontró en el año 1930 un momento clave para expandirse, debido a que esa fecha representaba la crisis del liberalismo. Sus objetivos consistieron en infiltrarse en el Estado y la sociedad para que "Cristo reine en nuestra patria". Estas ideas se materializaron en la organización de un evento significativos como fue el Congreso Eucarístico Internacional de 1934, allí hubo una homogenización interna del catolicismo y una irrupción masiva y organizada en el espacio público. Conjuntamente, en estos 
años se organizó una militancia más orgánica y activa, a la vez que se produjo un crecimiento de las instituciones religiosas, observado en la construcción de parroquias, escuelas, templos, en la implantación de placas y crucifijos en plazas y espacios públicos, en la publicación de libros y programas radiales que fueron construyendo una geografía católica en distintos espacios, que rivalizó con una geografía liberal y una geografía socialista.

En este sentido, el catolicismo emprendió un conflicto triangular con la ideología del liberalismo y del socialismo. La revista Criterio sostenía que el liberalismo era sinónimo de avaricia, rapiña, pérdida de valores, desorden, concupiscencia y nudismo. También se criticaba al diario La Prensa por considerar que sus noticias eran frívolas, sensacionalistas, sensuales, oportunistas y fruto del caos provocado por el libertinaje liberal. El socialismo también era objeto de impugnación. Desde 1932 la revista Criterio publicaba una columna titulada "Crímenes y vejámenes del comunismo en el mundo entero" en la que se sostenía que los bolcheviques constituían el proceso último de una serie de corrupciones degradantes iniciadas en el Renacimiento y en la reforma luterana; los socialistas, por su parte, apoyaban en la separación de la Iglesia y el Estado y la persecución a las congregaciones religiosas. La misma revista terminaba sintetizando el enfrentamiento: "Roma o Moscú (...) Roma o Washington, no hay otra opción".

Desde ese posicionamiento ideológico la Iglesia buscó recristianizar la sociedad y para ello recurrió a la creación de nuevas instituciones como la Acción Católica Argentina. Creada en mayo de 1931, ésta fue el largo brazo de la jerarquía eclesiástica que preparó a un grupo de dirigentes católicos para intervenir en distintos sectores de la sociedad. A la par se crearon diversas ramas: la Asociación de Mujeres de la Acción Católica, la Asociación Nacional de Hombres Católicos, la Federación Juvenil Católica. Estas instituciones eran lugares de aprendizaje político y de socialización donde sus integrantes aprendieron a hablar en público, a dirigir pequeños grupos y conducir grandes asambleas, a negociar, a discutir, a redactar informes y hacer síntesis, a decidir cuándo y cómo se termina una asamblea. Momento clave en la vida institucional eran las asambleas federales debido a que había que viajar, iniciar nuevas relaciones, descubrir otras ciudades, compartir días enteros con otros católicos. Esas asambleas reunieron, según sus propios números, en el año 1933 a 1400 participantes, en 1937 a 3300, y en 1943 a 7000. 
En "Miradas largas sobre los catolicismos y el mundo del trabajo", cuarto capítulo del libro, el autor indaga la interacción existente entre determinados elementos del catolicismo y su encuadramiento en la acción política, alrededor de la elaboración de principios éticos ligados a la significación del trabajo. Para ello toma tres momentos históricos: la experiencia peronista de 1946 a 1955, la militancia católica entre 1960 y 1970 y la situación actual. En el primero, a través del análisis de los discursos del sacerdote Hernán Benítez, Eva Perón y Juan D. Perón, identifica un intento de resignificación del catolicismo caracterizado por acentuar sus rasgos populares y obreros, romper con los imaginarios de los órdenes sociales y resaltar una retórica en contra de la jerarquía institucional eclesiástica. Es representantivo el discurso de Eva Perón al decir: "Reconocemos más que una clase de hombres: la de los que trabajan y Juan Perón decía: Cristo aparece como un defensor de los humildes (...) el cristianismo es la expresión de los oprimidos, la religión de los esclavos, de los libertos, de los pobres, de los pueblos sometidos al despotismo de Roma". En el segundo momento, entre los años 60 y 70, reconoce una relación entre el movimiento tercermundista y la militancia insurreccional, particularmente la de la izquierda peronista. El mundo católico iba hacia el mundo de los pobres, hacia el pueblo trabajador por lo que se encontraba con el peronismo. El surgimiento de Montoneros es el más claro ejemplo de este vínculo. En el tercer momento, el proceso de represión política y social y de desindustrialización llevado adelante por políticas neoliberales reactivó algunos sectores católicos que se enfrentaron a estas políticas. Resulta representativo la participación del sacerdote Alberto Spagnuolo en el Movimiento de Trabajadores Desocupados Aníbal Verón, en el que sigue presente el discurso del trabajo.

En el capítulo 5, titulado “Catolicismo y militarización. Catolicismos y militarismos", Mallimaci analiza la militarización del catolicismo y la catolización de las Fuerzas Armadas en el largo proceso que va desde 1930 hasta el reconstrucción de la democracia. A partir del golpe de Uriburu comenzó un lento y persistente proceso de militarización de la sociedad argentina. Desde el mundo católico se intervino - no sin tensiones internas- para posicionarse ante acontecimientos internacionales como la Guerra Civil Española y la Segunda Guerra Mundial. Desde la revista Criterio se preanunció el golpe de 1943 porque "el estado militar es, fuera del eclesiástico, el más sometido a disciplina y está 
destinado a mantener intactas las instituciones fundamentales del país, formará bloque contra quienes pretendan destruirla". En consecuencia, fue abundante la participación de católicos integristas en el gobierno militar iniciado en junio de 1943. El peronismo emergente se vinculó con el mundo católico, aunque también se produjeron enfrentamientos — como el intento de golpe de 1951 y los episodios previos al golpe de septiembre de 1955- en los que se manifestaron relaciones entre sectores católicos y militares. En 1958, el triunfo de la enseñanza libre representó otro impulso para que se expandiera por todo el país la educación católica con subsidio del Estado. Los golpe de 1966 y de 1976 fueron instancias de mutua retroalimentación entre el catolicismo integral y el militarismo. En el último golpe de Estado se acentuó la participación de los sectores católicos en la lucha contra la "subversión", incluso para reprimir a otros católicos como al Movimiento de Sacerdotes para el Tercer Mundo. En síntesis, como sostiene el autor, las relaciones entre el catolicismo y las Fuerzas Armadas fueron cambiando: hacia principios del siglo XX eran casi nulas y en la décadas de 1970 y 1980 llegaron a su apogeo. Es decir, no fue una relación esencial, que se direccionó en un sentido de la historia, sino que fue construida y buscada por ambos actores.

El último capítulo, "Católicos sin Iglesia e Iglesia sin catolicismo: la Argentina pluralista y democrática", analiza el mundo religioso en la transición a la democracia y lo define como de un catolicismo sin Iglesia debido a una proliferación de la individualización de las creencias evitando las mediaciones institucionales. En este sentido, hay una disminución de la adscripción al catolicismo y un distanciamiento de sus creyentes frente a las normas y prescripciones doctrinales. El autor identifica que esta situación se debe a que la población argentina comenzó un deslizamiento hacia otras religiones cristianas (evangélicos, entre otras) como así también a la maduración de una sociedad más democrática que buscó ampliar derechos. Al mismo tiempo, recorre la relación que tuvieron los gobiernos democráticos argentinos con la institución católica. Señala que Alfonsín tuvo momentos de tensión debido a la incorporación de representantes de otras religiones en temas claves como la organización de la CONADEP, la reforma educativa, así como la aprobación de la ley de divorcio. Los sectores católicos apoyaban las marchas que los sindicalistas realizaban contra el gobierno radical. Los gobiernos de los presidentes Menen y De la Rúa 
mejoraron las vínculos con la institución eclesiástica porque el primero defendió causas católicas como la oposición al aborto, la implementación del 25 de marzo como el Día del niño por nacer y el voto en conjunto del gobierno nacional y el Vaticano en la ONU contra los derechos de las mujeres. Los gobiernos de los Kirchner tuvieron una autonomía relativa debido a que tomaron distancia y se implementaron algunas medidas que la Iglesia cuestionó duramente, como la crítica a su participación junto a las Fuerzas Armadas en el terrorismo de Estado, el reconocimiento de los derechos sexuales y reproductivos y la expulsión de Antonio Baseotto del cargo de obispo castrense cuando sugirió que "le cuelguen una piedra de molino al cuello y lo tiren al mar" refiriéndose al ministro de Salud que proponía la distribución de preservativos entre los jóvenes. A pesar de estas últimas medidas - junto a otras como la aprobación del matrimonio igualitario-Mallimacci sostiene que no suponen necesariamente el tránsito hacia una cultura política más laica de separación entre los grupos religiosos, el Estado y los partidos. A la par, la elección de Jorge Bergoglio como Papa representa un florecimiento de la identidad católica. 